\title{
GROWTH-FORM RESPONSES TO FIRE IN NAMA-KAROO ESCARPMENT GRASSLAND, SOUTH AFRICA
}

\author{
Tineke Kraaij $^{1 *}$, Cyanne Young ${ }^{1}$, and Hugo Bezuidenhout ${ }^{2,3}$ \\ ${ }^{1}$ Nelson Mandela University, School of Natural Resource Management, \\ Private Bag X6531, George, 6530, South Africa \\ ${ }^{2}$ South African National Parks, Scientific Services, Kimberley Office, \\ P.O. Box 110040, Hadison Park, Kimberley, 8306, South Africa \\ ${ }^{3}$ Applied Behavioural Ecology and Ecosystem Research Unit, UNISA, \\ Private Bag X6, Florida, 1717, South Africa
}

*Corresponding author: Tel: +27-44-801-5018; e-mail: tineke.kraaij@mandela.ac.za

\begin{abstract}
Fire is a rare phenomenon in the semi-arid Nama-Karoo region of South Africa, but appears to have become more common in recent years, possibly as a result of climate change. The ecological effects of fire in this vegetation are poorly understood, but are likely to involve changes in structural composition, that of the shrub-grass ratio in particular. A fire burned an area of Karoo escarpment grassland (a mixture of shrubs and grasses) on the Nuweveld Mountains in October 2013. We assessed changes in plant structural composition and fire survival or persistence strategies of perennial shrubs at 2.5 years post fire. The canopy cover abundance of grasses, herbs, and dwarf shrubs increased post fire, while that of large shrubs decreased. Despite all large shrub species (except Elytropappus rhinocerotis [L.f.] Less.) exhibiting post-fire resprouting and reseeding, vigor varied widely within species. Localized post-fire extinctions appeared possible in many large shrub
\end{abstract}

\section{RESUMEN}

El fuego es un fenómeno raro en la región semiárida Nama-Karoo de Sudáfrica, pero aparece como más común en años recientes, posiblemente como resultado del cambio climático. Los efectos ecológicos del fuego en la vegetación de esta región son muy poco conocidos, pero es probable que impliquen cambios en su composición estructural, en particular en la relación pastos-arbustos. En octubre de 2013, un incendio quemó un área de pastizal escarpado (mezcla de pastos y arbustos) en el área de Karoo sobre las montañas Nuweveld. Allí y 2,5 años post fuego, determinamos cambios en la composición estructural de la vegetación y las estrategias de supervivencia y persistencia de arbustos perennes. La cobertura del dosel, la abundancia de pastos, hierbas, y arbustos enanos se incrementaron luego del fuego, mientras que la de los arbustos grandes disminuyó. A pesar de que las especies de grandes arbustos (con excepción de Elytropappus rhinocerotis [L.f.] Less.) exhibieron estrategias de rebrote y resiembra de semillas post-fuego, el vigor varió significativamente entre especies. La extinción localizada post-fuego pareciera posible en algunas espe- 
species, including Cliffortia arborea Marloth (Vulnerable; Raimondo et al. 2015). Increases in fire frequency or fire intensity are predicted to result in persistent negative feedbacks (the grass-fire cycle) whereby the herbaceous stratum would increase in dominance at the expense of larger woody growth forms. This process may be hindered by actions to prevent and suppress fires. cies de arbustos grandes, incluyendo Cliffortia arborea Marloth (especie vulnerable; Raimondo et al. 2015). Predecimos que el incremento en la frecuencia de fuegos puede resultar en retroalimentaciones negativas persistentes (el ciclo fuego-pastos) en las cuales el estrato herbáceo podría incrementar su dominancia a expensas de formas de crecimiento de arbustos leñosos grandes. Este proceso puede ser limitado mediante acciones de prevención y supresión de incendios.

Keywords: fire sensitive, fire survival and persistence strategies, Karoo National Park, Nuweveld Mountains, post-fire recruitment, semi-arid vegetation, shrub-grass dynamics

Citation: Kraaij, T., C. Young, and H. Bezuidenhout. 2017. Growth-form responses to fire in Nama-Karoo escarpment grassland, South Africa. Fire Ecology 13(3): 85-94. doi: 10.4996/ fireecology.130308594

\section{INTRODUCTION}

The Nama-Karoo of South Africa is a semi-arid biome with infrequent historical fire occurrence and perennial dwarf shrubs and grasses considered to be fire independent and fire sensitive (Mucina et al. 2006, Le Maitre et al. 2014). Recently, fire has become more common in the Nama-Karoo (Du Toit et al. 2016) and other arid ecosystems (Syphard et al. 2017), potentially threatening the persistence of native species. Increases in fire occurrence may result from changing climate and resultant increases in fire-prone weather conditions (Wilson et al. 2010, Kraaij et al. 2013), or changes in the structural composition of vegetation affecting fuel attributes of ecosystems (D'Antonio and Vitousek 1992, Rahlao et al. 2009, Syphard et al. 2017). Increased grassiness in arid shrublands promotes fuel continuity, thereby resulting in increased occurrences of fire (D'Antonio and Vitousek 1992, Brooks et al. 2004, Nicholas et al. 2009). This has been seen in grassy Nama-Karoo, where sufficient grassy fuels may accumulate in high rainfall years to sustain fires (Le Maitre et al. 2014), or with the invasion of arid shrublands by alien grasses in the Karoo (Rahlao et al. 2009) and elsewhere (Brooks et al. 2004, Balch et al. 2013, Syphard et al. 2017). Given that grasses are usually more tolerant of fire than shrubs, the combination of grasses and fire could initiate a persistent negative feedback called the grass-fire cycle (D'Antonio and Vitousek 1992, Brooks et al. 2004, Rahlao et al. 2009, Keeley and Brennan 2012).

Shrub-grass ratios in semi-arid vegetation (including the Nama-Karoo) are influenced by several factors; grassiness mostly increases with the amount and reliability of rainfall, a greater proportion of summer rainfall (i.e., from west to east in the Nama-Karoo), altitude, and long-term reductions in livestock grazing pressure (Kraaij and Milton 2006; Mucina et al. 2006; Nicholas et al. 2009; Brooks and Chambers 2011; Du Toit et al. 2015, 2016). The literature dealing with Karoo vegetation is dominated by phytosociological descriptions of the flora, and studies on vegetation structural and compositional responses to rainfall and utilization by herbivores (Rubin and Palmer 1996, Rubin et al. 2001, Kraaij and Milton 2006, Mucina et al. 
2006). However, given the rarity of fire in Karoo systems, plant tolerance of fire is poorly studied (Du Toit et al. 2015). The resilience of arid vegetation to fire is thought to increase along rainfall and nutrient ( $\sim$ primary productivity) gradients (Brooks and Chambers 2011). Post-fire recruitment abilities of Karoo vegetation would thus be expected to improve with increasing rainfall from west to east and with altitude ( $c f$. Brooks and Chambers 2011). Limited evidence from the eastern Nama-Karoo suggests that fire leads to increases in grassiness (Roux and Vorster 1983, Du Toit et al. 2016) and that most shrubs are able to resprout after fire (Du Toit et al. 2015). However, in Succulent Karoo, a drier vegetation with little grass, very few species of dwarf shrubs were able to resprout post fire (Rahlao et al. 2009, Van der Merwe et al. 2016).

Given the inadequate understanding of plant (shrubs in particular) responses to fire, we aimed to (1) assess changes in plant growth-form composition resulting from fire in westernmost grassy Nama-Karoo vegetation; and (2) characterize fire survival or persistence strategies of perennial shrubs in this vegetation. Improved knowledge of vegetation responses to fire should inform the management of fire to facilitate biodiversity conservation in Nama-Karoo ecosystems.

\section{METHODS}

The study area was the Puttersvlei section of the Karoo National Park on the upper plateau of the Nuweveld Mountains (altitude $1676 \mathrm{~m}$ above sea level; 32 $13^{\prime} 12^{\prime \prime} \mathrm{S}$, $22^{\circ} 31^{\prime} 12^{\prime \prime} \mathrm{E}$ to $32^{\circ} 16^{\prime} 12^{\prime \prime} \mathrm{S}, 22^{\circ} 28^{\prime} 48^{\prime \prime} \mathrm{E}$ ). The vegetation is a mixture of shrubs and grasses, composed of two vegetation units: Upper Karoo Hardeveld (Nama-Karoo Biome), and the westernmost occurrence of Karoo Escarpment Grassland (Grassland Biome) (Mucina et al. 2006). Mean annual rainfall is $406 \mathrm{~mm}$, mean daily temperatures are $5^{\circ} \mathrm{C}$ in July (winter) and $18^{\circ} \mathrm{C}$ in February (summer), with the ab- solute minimum-maximum range being $-1{ }^{\circ} \mathrm{C}$ to $34^{\circ} \mathrm{C}$ (Rubin and Palmer 1996). The geology is dolerite rocks with underlying sandstone appearing in terraces (Rubin and Palmer 1996).

Rubin and Palmer (1996) surveyed the vegetation at Puttersvlei in plots (each $10 \mathrm{~m} \times$ $10 \mathrm{~m}$ ) as part of a larger study that produced a phytosociological description of the park. We re-surveyed 22 of these plots during April 2016, 2.5 yr after a human-induced fire (8 to 12 October 2013) burned an area of 2500 ha. We repeated the methods of Rubin and Palmer (1996) by recording all plant species present in each plot. We assigned each species to a cover value class (Werger 1974) and used the midrange projected canopy cover values of the respective classes (i.e., $0.01 \%, 0.5 \%, 2.5 \%$, $8.5 \%, 19.0 \%$, and $37.5 \%$ ). We furthermore classified each species by growth form according to a simplified version of the categorization by Rubin et al. (2001), as follows: graminoid, herb (including herbs, ferns, and geophytes), dwarf shrub, and large shrub (including shrubs and trees). We detected potential discrepancies in species identifications and canopy cover estimates between the 1996 (hereafter pre fire) and 2016 (hereafter post fire) studies. Fifty-eight of 163 species were recorded in both studies, while 55 species were recorded only pre fire and 50 species only post fire. To account for potential discrepancies in projected canopy cover estimates, we assessed changes between pre-fire and post-fire periods in terms of absolute and relative cover abundances of growth forms. Relative canopy cover was calculated as the percentage of the total (summed) vegetation canopy cover in a plot represented by each respective growth form. We compared relative and absolute cover per growth form within the same plots between pre-fire and post-fire periods. The data did not conform to normality; we thus used Wilcoxon matched pairs tests (Statistica v.13, Dell Inc., Tulsa, Oklahoma, USA). To explore species compositional 
changes, we counted the number of plots in which each species appeared or disappeared from the pre-fire to post-fire periods. To account for potential discrepancies in species identifications between the pre-fire and postfire studies, we limited this analysis to those species that were recorded in both studies.

We also assessed the fire survival or persistence strategies of seven large shrub species that were abundant in particular localities (outside of plots) prior to the fire. We counted the respective numbers of resprouting, reseeding, and dead individuals post fire in $10 \mathrm{~m}$ wide belt transects. The length of transects varied (range $50 \mathrm{~m}$ to $300 \mathrm{~m}$ ) to allow for inclusion of sufficient numbers of individuals (preferably $\geq 100$ ) per species per locality. Large shrub species were assessed at various localities (one to three localities per species; Table 1), depending on the availability of sufficiently dense populations. For each population sampled, we calculated (1) the ratio of the post-fire population (sum of all reseeding and resprouting individuals) to the pre-fire population (sum of resprouters and mortalities); (2) the percentage resprouting (number of resprouters divided by the pre-fire population $\times 100$ ); and (3) the percentage reseeding (number of post-fire seedlings divided by the pre-fire population $\times$ 100). Nomenclature follows Raimondo et al. (2015) (see Appendix 1).

\section{RESULTS}

From pre-fire to post-fire periods, absolute cover increased significantly in grasses $\left(Z_{1,21}=\right.$ 2.06, $P=0.039)$, herbs $\left(Z_{1,21}=3.00, \stackrel{P}{P}=\right.$ $0.002)$, and dwarf shrubs $\left(Z_{1,21}=3.26, P=\right.$ $0.001)$, but not in large shrubs $\left(Z_{1,21}=1.42, P=\right.$ 0.154) (Figure 1). In terms of relative cover, grasses remained unchanged $\left(Z_{1,21}=0.08, P=\right.$ $0.935)$ from pre-fire to post-fire, while herbs $\left(Z_{1,21}=2.64, P=0.008\right)$ and dwarf shrubs $\left(Z_{1,21}\right.$ $=2.38, P=0.017$ ) increased significantly, and large shrubs decreased significantly $\left(Z_{1,21}=\right.$ 2.06, $P=0.039$ ).

The extent to which large shrub species persisted through fire varied widely, with postfire population sizes ranging from zero to sixfold the pre-fire population sizes (Table 1). All the assessed species, except Elytropappus rhinocerotis, displayed the ability to resprout after fire. Resprouting vigor was high in Helichrysum trilineatum, Diospyros austro-africana and Anthospermum spathulatum, weak in Cliffortia arborea and Euryops annae, and

Table 1. The extent of fire survival or persistence displayed 2.5 years after fire by large shrub species in a Nama-Karoo montane shrubby grassland, South Africa. Measures reported are based on numbers of individuals and calculated as detailed under Methods.

\begin{tabular}{lcccccc}
\hline \multicolumn{1}{c}{ Species } & $\begin{array}{c}\text { Post: } \\
\text { pre-fire } \\
\text { population }\end{array}$ & $\begin{array}{c}\text { Resprouting } \\
(\%)\end{array}$ & $\begin{array}{c}\text { Reseeding } \\
(\%)\end{array}$ & $\begin{array}{c}\text { Plants } \\
\text { surveyed } \\
(\boldsymbol{n})\end{array}$ & $\begin{array}{c}\text { Latitude } \\
\left({ }^{\circ}\right)\end{array}$ & $\begin{array}{c}\text { Longitude } \\
\text { (\%) }\end{array}$ \\
\hline Passerina montana & 6.40 & 100 & 540 & 32 & $32^{\circ} 15^{\prime} 41^{\prime \prime} \mathrm{S} 22^{\circ} 29^{\prime} 43^{\prime \prime} \mathrm{E}$ \\
Passerina montana & 2.47 & 30 & 217 & 168 & $32^{\circ} 15^{\prime} 27^{\prime \prime} \mathrm{S}$ & $22^{\circ} 30^{\prime} 10^{\prime \prime} \mathrm{E}$ \\
Passerina montana & 0.14 & 0 & 14 & 123 & $32^{\circ} 12^{\prime} 45^{\prime \prime} \mathrm{S}$ & $22^{\circ} 31^{\prime} 35^{\prime \prime} \mathrm{E}$ \\
Helichrysum trilineatum & 2.72 & 100 & 172 & 136 & $32^{\circ} 15^{\prime} 34^{\prime \prime} \mathrm{S} 22^{\circ} 30^{\prime} 08^{\prime \prime} \mathrm{E}$ \\
Diospyros austro-africana & 2.26 & 91 & 135 & 54 & $32^{\circ} 15^{\prime} 34^{\prime \prime} \mathrm{S} 22^{\circ} 30^{\prime} 08^{\prime \prime} \mathrm{E}$ \\
Cliffortia arborea & 1.38 & 23 & 115 & 28 & $32^{\circ} 12^{\prime} 45^{\prime \prime} \mathrm{S} 22^{\circ} 31^{\prime} 35^{\prime \prime} \mathrm{E}$ \\
Cliffortia arborea & 1.28 & 37 & 91 & 122 & $32^{\circ} 15^{\prime} 34^{\prime \prime} \mathrm{S} 22^{\circ} 30^{\prime} 08^{\prime \prime} \mathrm{E}$ \\
Anthospermum spathulatum & 1.21 & 80 & 41 & 196 & $32^{\circ} 12^{\prime} 45^{\prime \prime} \mathrm{S} 22^{\circ} 31^{\prime} 25^{\prime \prime} \mathrm{E}$ \\
Euryops annae & 0.94 & 3 & 91 & 265 & $32^{\circ} 14^{\prime} 48^{\prime \prime} \mathrm{S} 22^{\circ} 28^{\prime} 56^{\prime \prime} \mathrm{E}$ \\
Euryops annae & 0.24 & 18 & 6 & 197 & $32^{\circ} 16^{\prime} 09^{\prime \prime} \mathrm{S} 22^{\circ} 29^{\prime} 40^{\prime \prime} \mathrm{E}$ \\
Elytropappus rhinocerotis & 0.00 & 0 & 0 & 89 & $32^{\circ} 16^{\prime} 09^{\prime \prime} \mathrm{S} 22^{\circ} 29^{\prime} 40^{\prime \prime} \mathrm{E}$ \\
\hline
\end{tabular}




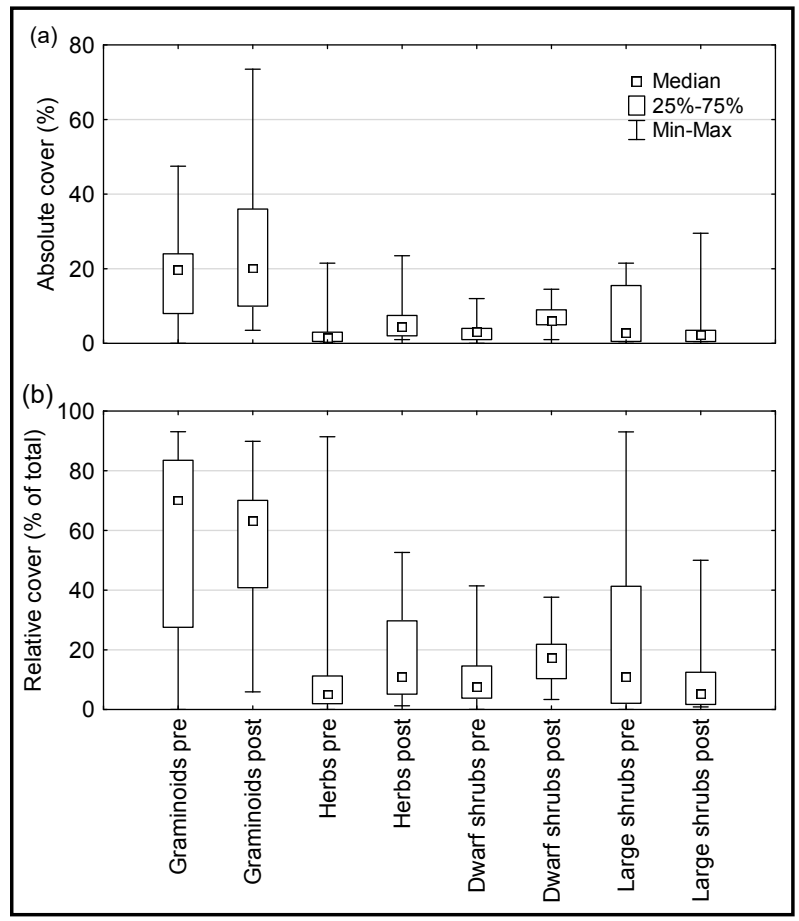

Figure 1. (a) Absolute and (b) relative projected canopy cover (expressed as a percentage of total vegetation cover) of various growth forms compared between pre-fire (Rubin and Palmer 1996) and post-fire (2016) periods in a Nama-Karoo montane shrubby grassland, South Africa.

varied among subpopulations of Passerina montana. All assessed species, except Elytropappus rhinocerotis, recruited from seed with large variations among and within species (Table 1). Seven out of 14 large shrub species declined from pre-fire to post-fire in terms of the number of plots that they occupied (Appendix $1)$.

\section{DISCUSSION}

We showed that fire resulted in increases or maintenance of grass cover in westernmost grassy Nama-Karoo vegetation, in accordance with findings for eastern Nama-Karoo vegetation (De Klerk et al. 2001, Du Toit et al. 2015). Additionally, we found that herbaceous plants and dwarf shrubs increased significantly after fire. Du Toit et al. (2015) did not report on re- sponses of herbs (other than grasses) to fire in the eastern Nama-Karoo, but herbs commonly abound in early successional stages of various vegetation types (Musil and De Witt 1990, Van der Merwe and Van Rooyen 2011, Bachinger et al. 2016). Most dwarf shrubs in Nama-Karoo appeared capable of resprouting after fire (Du Toit et al. 2015), whereas those in Succulent Karoo largely appeared incapable of postfire resprouting (Rahlao et al. 2009, Van der Merwe et al. 2016). This discrepancy may reflect disparate evolutionary histories and lower fire probabilities under the drier climatic conditions of the Succulent Karoo. We encountered very few succulent dwarf shrubs in our study, but other studies suggest that succulents are incapable of sprouting, although they may establish prolifically from seed after disturbance (Du Toit et al. 2015, Van der Merwe et al. 2016). The finding that dwarf shrubs mostly recovered well after fire in Nama-Karoo is encouraging for the maintenance of these shrublands should fires become more frequent in the future.

Large shrubs were the only growth form that decreased significantly after fire. Despite all large shrub species (except Elytropappus rhinocerotis) assessed in this study exhibiting resprouting abilities (as found by Du Toit et al. 2015), resprouting success varied widely within species. Some of the variation in resprouting appeared to be related to localized differences in fire intensity (T. Kraaij, Nelson Mandela University, George, South Africa, personal observation; $c f$. Van Wilgen 1980). Likewise, all assessed large shrub species, except E. rhinocerotis, recruited from seed to lesser or greater extents, again showing large variation among subpopulations within species. Collectively, our results suggest that more than half of the large shrub species that were assessed (including the iconic Cliffortia arborea, Red-listed as Vulnerable; Raimondo et al. 2015) may fail to sustain their populations after fire. These large shrubs displayed low post-fire:pre-fire population ratios (Table 1) or 
post-fire disappearance from the majority of plots (Appendix 1). The lack of post-fire recovery of Elytropappus rhinocerotis was contrary to its prolific reseeding after fires in fireprone renosterveld (Levyns 1972, Van der Merwe and Van Rooyen 2011). Its lack of recruitment may be due to the timing of fire in relation to seed production, the timing of postfire rainfall (S.J. Milton, RenuKaroo, Prince Albert, South Africa, personal communication), or high intensity of burning (T. Kraaij, personal observation). We showed that several species may be vulnerable to local extinction through fires despite possessing resprouting and reseeding abilities. This was detected through quantifying, as opposed to merely categorizing, fire survival and persistence responses of large shrubs, and through conducting surveys 2 to 3 years, rather than a few months, post fire.

The above suggests that specific attributes of individual fires and fire regimes (i.e., size, patchiness, fire intensity, fire return interval, and fire season) are likely to affect persistence of species and vegetation structure in the longterm ( $c f$. Vlok and Yeaton 2000, Parr and An- dersen 2006, Kraaij and Van Wilgen 2014). Furthermore, abundances of growth forms (and herbaceous species in particular) typically vary widely among years and with post-fire vegetation age (Musil and De Witt 1990, Van der Merwe and Van Rooyen 2011, Van der Merwe et al. 2016). Our study was limited to the effects of a single fire and to single observation events pre fire and post fire. The effects of different types of fires warrant further investigation, as do post-fire Karoo vegetation dynamics in the long term.

We predict that, with increases in the frequency or intensity of fires, the structure and composition of Nama-Karoo montane shrubby grasslands will undergo increases in the smaller growth forms (graminoids, other herbs, and dwarf shrubs) but decreases or potential loss of large shrubs. Such a scenario could mirror the persistent negative feedbacks, or grass-fire cycles, observed in certain other arid and semi-arid areas (D'Antonio and Vitousek 1992, Brooks et al. 2004). Consequently, we recommend that managers largely suppress the spread of man-made fires in protected areas comprising Nama-Karoo ecosystems.

\section{ACKNOWLEDGEMENTS}

We thank South African National Parks and the Nelson Mandela University for enabling the study; and K. Babilon, M. Ericksen, A. Johnson, and R. Nel for assistance with field data collection.

\section{LITERATURE CITED}

Bachinger, L.M., L.R. Brown, and M.W. Van Rooyen. 2016. The effects of fire-breaks on plant diversity and species composition in the grasslands of the Loskop Dam Nature Reserve, South Africa. African Journal of Range \& Forage Science 33:21-32. doi: 10.2989/10220119.2015.1088574

Balch, J.K., B.A. Bradley, C.M. D’Antonio, and J. Gómez-Dans. 2013. Introduced annual grass increases regional fire activity across the arid western USA (1980-2009). Global Change Biology 19(1): 173-183. doi: 10.1111/gcb.12046

Brooks, M.L., and J.C. Chambers. 2011. Resistance to invasion and resilience to fire in desert shrublands of North America. Rangeland Ecology and Management 64: 431-438. doi: 10.2111/REM-D-09-00165.1

Brooks, M.L., C.M. D’Antonio, D.M. Richardson, J.B. Grace, J.E. Keeley, J.M. DiTomaso, R.J. Hobbs, M. Pellant, and D. Pyke. 2004. Effects of invasive alien plants on fire regimes. Bioscience 54: 677-688. doi: 10.1641/0006-3568(2004)054[0677:EOIAPO]2.0.CO;2 
D'Antonio, C.M., and P.M. Vitousek. 1992. Biological invasions by exotic grasses, the grass/fire cycle, and global change. Annual Review of Ecology and Systematics 23: 63-87. doi: 10.1146/annurev.es.23.110192.000431

De Klerk, L.R. Brown, H. Bezuidenhout, and G. Castley. 2001. The estimation of herbage yields under fire and grazing treatments in the Mountain Zebra National Park. Koedoe 44(1): 9-15. doi: 10.4102/koedoe.v44i1.181

Du Toit, J.C.O., L. Van den Berg, and T.G. O'Connor. 2015. Fire effects on vegetation in a grassy dwarf shrubland at a site in the eastern Karoo, South Africa. African Journal of Range \& Forage Science 32: 13-20. doi: 10.2989/10220119.2014.913077

Du Toit, J.C.O., T.G. O’Connor, and L. Van den Berg. 2016. Photographic evidence of fire-induced shifts from dwarf-shrub- to grass-dominated vegetation in Nama-Karoo. South African Journal of Botany 101: 148-152. doi: 10.1016/j.sajb.2015.06.002

Keeley, J.E., and T.J. Brennan. 2012. Fire-driven alien invasion in a fire-adapted ecosystem. Oecologia 169: 1043-1052. doi: 10.1007/s00442-012-2253-8

Kraaij, T., and S.J. Milton. 2006. Vegetation changes (1995-2004) in semi-arid Karoo shrubland, South Africa: Effects of rainfall, wild herbivores and change in land use. Journal of Arid Environments 64: 174-192. doi: 10.1016/j.jaridenv.2005.04.009

Kraaij, T., and B.W. Van Wilgen. 2014. Drivers, ecology, and management of fire in fynbos. Pages 47-72 in: N. Allsopp, J.F. Colville, and G.A. Verboom, editors. Fynbos: ecology, evolution, and conservation of a megadiverse region. Oxford University Press, Oxford, England, United Kingdom. doi: 10.1093/acprof:oso/9780199679584.003.0003

Kraaij, T., R.M. Cowling, and B.W. Van Wilgen. 2013. Lightning and fire weather in eastern coastal fynbos shrublands: seasonality and long-term trends. International Journal of Wildland Fire 22: 288-295. doi: 10.1071/WF11167

Le Maitre, D.C., F.J. Kruger, and G.G. Forsyth. 2014. Interfacing ecology and policy: developing an ecological framework and evidence base to support wildfire management in South Africa. Austral Ecology 39: 424-436. doi: 10.1111/aec.12100

Levyns, M.R. 1972. The rhenosterbush. Veld \& Flora 2(1): 7-9.

Mucina, L., M.C. Rutherford, A.R. Palmer, S.J. Milton, L. Scott, J.W. Lloyd, B. Van der Merwe, D.B. Hoare, H. Bezuidenhout, J.H.J. Vlok, D.I.W. Euston-Brown, L.W. Powrie, and A.P. Dold. 2006. Nama-Karoo Biome. Pages 324-347 in: L. Mucina and M.C. Rutherford, editors. The vegetation of South Africa, Lesotho and Swaziland. South African National Biodiversity Institute, Pretoria.

Musil, C.F., and D.M. De Witt. 1990. Post-fire regeneration in a sand plain lowland fynbos community. South African Journal of Botany 56: 167-184. doi: 10.1016/S0254-6299(16)31084-5

Nicholas, A.M.M., D.C. Franklin, and D.M.J.S. Bowman. 2009. Coexistence of shrubs and grass in a semi-arid landscape: a case study of mulga (Acacia aneura, Mimosaceae) shrublands embedded in fire-prone spinifex (Triodia pungens, Poaceae) hummock grasslands. Australian Journal of Botany 57: 396-405. doi: 10.1071/BT07157

Parr, C.L., and A.N. Andersen. 2006. Patch mosaic burning for biodiversity conservation: a critique of the pyrodiversity paradigm. Conservation Biology 20: 1610-1619. doi: 10.1111/j.1523-1739.2006.00492.x

Rahlao, S.J., S.J. Milton, K.J. Esler, B.W. Van Wilgen, and P. Barnard. 2009. Effects of invasion of fire-free arid shrublands by a fire-promoting invasive alien grass (Pennisetum setaceum) in South Africa. Austral Ecology 34(8): 920-928. doi: 10.1111/j.1442-9993.2009.02000.x 
Raimondo, D., L. Von Staden, W. Foden, J.E. Victor, N.A. Helme, R.C. Turner, D. Kamundi, and P. Manyama, editors. 2015. National assessment: Red list of South African plants, version 2015.1. South African National Biodiversity Institute, Pretoria.

Roux, P.W., and M. Vorster. 1983. Development of veld management research in the Karoo region. Proceedings of the Grassland Society of Southern Africa 18: 30-34. doi: 10.1080/00725560.1983.9648977

Rubin, F., and A.R. Palmer. 1996. The physical environment and major plant communities of the Karoo National Park, South Africa. Koedoe 39: 25-52. doi: 10.4102/koedoe.v39i2.293

Rubin, F., A.R. Palmer, and C. Tyson. 2001. Patterns of endemism within the Karoo National Park, South Africa. Bothalia 31(1): 117-133. doi: 10.4102/abc.v31i1.510

Syphard, A.D., J.E. Keeley, and J.T. Abatzoglou. 2017. Trends and drivers of fire activity vary across California aridland ecosystems. Journal of Arid Environments 144: 110-122. doi: 10.1016/j.jaridenv.2017.03.017

Van der Merwe, H., and M.W. Van Rooyen. 2011. Vegetation trends following fire in the Roggeveld, Mountain Renosterveld, South Africa. South African Journal of Botany 77: 127-136. doi: 10.1016/j.sajb.2010.07.009

Van der Merwe, H., S. Rahlao, L. Hein, and S.J. Milton. 2016. Vegetation dynamics after experimental fire disturbance in the arid Succulent Karoo, South Africa. African Journal of Range \& Forage Science 33: 131-135. doi: 10.2989/10220119.2016.1173098

Van Wilgen, B.W. 1980. Assessment of the effects of burning on populations of the Clanwilliam cedar using aerial photography. South African Forestry Journal 114: 72-74. doi: 10.1080/00382167.1980.9629838

Vlok, J.H.J., and R.I. Yeaton. 2000. The effect of short fire cycles on the cover and density of understorey sprouting species in South African mountain fynbos. Diversity and Distributions 6: 233-242. doi: 10.1046/j.1472-4642.2000.00087.x

Werger, M.J.A. 1974. On concepts and techniques applied in the Zürich-Montpellier method of vegetation survey. Bothalia 11(3): 309-323. doi: 10.4102/abc.v11i3.1477

Wilson, A.M., A.M. Latimer, J.A. Silander Jr., A.E. Gelfand, and H. De Klerk. 2010. A hierarchical Bayesian model of wildfire in a Mediterranean biodiversity hotspot: implications of weather variability and global circulation. Ecological Modelling 221: 106-112. doi: 10.1016/j.ecolmodel.2009.09.016 
Appendix 1. Trends in species appearance or disappearance (expressed in terms of numbers of plots) from pre-fire (Rubin and Palmer 1996) to post-fire (2016) periods in a Nama-Karoo montane shrubby grassland, South Africa. Only species observed in both studies were considered. Species are categorized by growth form, and species that decreased from pre fire to post fire are shown in bold. Growth-form categorization follows Rubin et al. (2001) and nomenclature follows Raimondo et al. (2015).

\begin{tabular}{|c|c|c|c|c|c|}
\hline Family & Species & $\begin{array}{c}\text { Ratio of } \\
\text { post:pre-fire } \\
\text { occurrence }\end{array}$ & $\begin{array}{l}\text { Recorded } \\
\text { pre fire } \\
(n)\end{array}$ & $\begin{array}{l}\text { Recorded } \\
\text { post fire } \\
(n)\end{array}$ & $\begin{array}{c}\text { Plots that } \\
\text { had species } \\
\text { appear }(+) \text { or } \\
\text { disappear }(-) \\
(n)\end{array}$ \\
\hline \multicolumn{6}{|l|}{ GRAMINOIDS } \\
\hline Poaceae & Eragrostis chloromelas Steud. & 3.33 & 3 & 10 & 7 \\
\hline Poaceae & Cymbopogon caesius (Hook. \& Arn.) Stapf & 3.00 & 3 & 9 & 6 \\
\hline Poaceae & Ehrharta calycina Sm. & 3.00 & 1 & 3 & 2 \\
\hline Poaceae & Heteropogon contortus (L.) Roem. \& Schult. & 2.00 & 1 & 2 & 1 \\
\hline Poaceae & Themeda triandra Forssk. & 1.75 & 8 & 14 & 6 \\
\hline Poaceae & $\begin{array}{l}\text { Tenaxia disticha (Nees) N.P.Barker \& } \\
\text { H.P.Linder }\end{array}$ & 1.22 & 18 & 22 & 4 \\
\hline Cyperaceae & Cyperus marginatus Thunb. & 1.00 & 1 & 1 & 0 \\
\hline Poaceae & Eragrostis curvula (Schrad.) Nees & 0.75 & 8 & 6 & -2 \\
\hline Poaceae & $\begin{array}{l}\text { Cymbopogon pospischilii (K.Schum.) } \\
\text { C.E.Hubb. }\end{array}$ & 0.50 & 2 & 1 & -1 \\
\hline Poaceae & Enneapogon desvauxii P.Beauv. & 0.33 & 3 & 1 & -2 \\
\hline Poaceae & Melica racemosa Thunb. & 0.33 & 3 & 1 & -2 \\
\hline \multicolumn{6}{|l|}{ HERBS } \\
\hline Sterculiaceae & Hermannia althaeifolia $\mathrm{L}$. & 15.00 & 1 & 15 & 14 \\
\hline Oxalidaceae & Oxalis commutata Sond. & 15.00 & 1 & 15 & 14 \\
\hline Fabaceae & Lotononis tenella (E.Mey.) Eckl. \& Zeyh. & 12.00 & 1 & 12 & 11 \\
\hline Asteraceae & Senecio inaequidens DC. & 12.00 & 1 & 12 & 11 \\
\hline Adiantaceae & Cheilanthus eckloniana (Kunze) Mett. & 4.00 & 2 & 8 & 6 \\
\hline Asteraceae & Berkheya glabrata (Thunb.) Fourc. & 3.50 & 2 & 7 & 5 \\
\hline Scrophulariaceae & Jamesbrittenia foliolosa (Benth.) Hilliard & 3.00 & 2 & 6 & 4 \\
\hline Aspleniaceae & Asplenium cordatum (Thunb.) Sw. & 1.00 & 1 & 1 & 0 \\
\hline Crassulaceae & Crassula dependens Bolus & 1.00 & 1 & 1 & 0 \\
\hline Caryophyllaceae & Dianthus micropetalus Ser. var. & 1.00 & 2 & 2 & 0 \\
\hline Dipsaceae & Scabiosa columbaria $\mathrm{L}$. & 1.00 & 1 & 1 & 0 \\
\hline Caryophyllaceae & Dianthus thunbergii S.S.Hooper & 0.67 & 3 & 2 & -1 \\
\hline Scrophulariaceae & Aptosimum procumbens (Lehm.) Steud. & 0.50 & 4 & 2 & -2 \\
\hline Selaginaceae & Selago saxatilis E.Mey. & 0.38 & 8 & 3 & -5 \\
\hline Asphodelaceae & Kniphofia uvaria (L.) Oken & 0.33 & 3 & 1 & -2 \\
\hline Scrophulariaceae & Nemesia fruticans (Thunb.) Benth. & 0.33 & 3 & 1 & -2 \\
\hline \multicolumn{6}{|l|}{ DWARF SHRUBS } \\
\hline Polygalaceae & Polygala virgata Thunb. & 7.00 & 1 & 7 & 6 \\
\hline Asteraceae & Felicia fascicularis DC. & 6.00 & 2 & 12 & 10 \\
\hline Selaginaceae & Selago geniculata L.f. & 5.50 & 2 & 11 & 9 \\
\hline Campanulaceae & Wahlenbergia nodosa (H.Buek) Lammers & 3.67 & 3 & 11 & 8 \\
\hline Fabaceae & $\begin{array}{l}\text { Melolobium microphyllum (L.f.) Eckl. \& } \\
\text { Zeyh. }\end{array}$ & 3.67 & 3 & 11 & 8 \\
\hline Asteraceae & Felicia muricata (Thunb.) Nees & 3.00 & 3 & 9 & 6 \\
\hline Fabaceae & Indigofera heterophylla Thunb. & 3.00 & 2 & 6 & 4 \\
\hline Asteraceae & Helichrysum zeyheri Less. & 3.00 & 1 & 3 & 2 \\
\hline Asteraceae & Helichrysum rugulosum Less. & 2.33 & 3 & 7 & 4 \\
\hline Rubiaceae & Nenax microphylla (Sond.) T.M.Salter & 1.00 & 2 & 2 & 0 \\
\hline Geraniaceae & Pelargonium alternans J.C.Wendl. & 1.00 & 1 & 1 & 0 \\
\hline Lamiaceae & Stachys rugosa Aiton & 0.70 & 10 & 7 & -3 \\
\hline
\end{tabular}


Appendix 1, continued. Trends in species appearance or disappearance (expressed in terms of numbers of plots) from pre-fire (Rubin and Palmer 1996) to post-fire (2016) periods in a Nama-Karoo montane shrubby grassland, South Africa. Only species observed in both studies were considered. Species are categorized by growth form, and species that decreased from pre fire to post fire are shown in bold. Growthform categorization follows Rubin et al. (2001) and nomenclature follows Raimondo et al. (2015).

\begin{tabular}{|c|c|c|c|c|c|}
\hline Family & Species & $\begin{array}{c}\text { Ratio of } \\
\text { post:pre-fire } \\
\text { occurrence }\end{array}$ & $\begin{array}{l}\text { Recorded } \\
\text { pre fire } \\
(n)\end{array}$ & $\begin{array}{l}\text { Recorded } \\
\text { post fire } \\
(n)\end{array}$ & $\begin{array}{c}\text { Plots that } \\
\text { had species } \\
\text { appear }(+) \text { or } \\
\text { disappear }(-) \\
(n)\end{array}$ \\
\hline Fabaceae & $\begin{array}{l}\text { Lessertia frutescens (L.) Goldblatt \& } \\
\text { J.C.Manning }\end{array}$ & 0.50 & 2 & 1 & -1 \\
\hline Asteraceae & Pteronia sordida N.E.Br. & 0.33 & 3 & 1 & -2 \\
\hline Asteraceae & Felicia hirsuta DC. & 0.33 & 6 & 2 & -4 \\
\hline Asteraceae & Chrysocoma ciliata $\mathrm{L}$. & 0.22 & 9 & 2 & -7 \\
\hline \multicolumn{6}{|l|}{ LARGE SHRUBS } \\
\hline Malvaceae & Anisodontea malvastroides (Baker f.) Bates & 2.50 & 2 & 5 & 3 \\
\hline Asparagaceae & Asparagus capensis $\mathrm{L}$. & 1.50 & 2 & 3 & 1 \\
\hline Ebenaceae & Diospyros austro-africana De Winter & 1.22 & 9 & 11 & 2 \\
\hline Thymelaeaceae & Passerina montana Thoday & 1.20 & 10 & 12 & 2 \\
\hline Rhamnaceae & Rhamnus prinoides L'Hér. & 1.00 & 2 & 2 & 0 \\
\hline Anacardiaceae & Searsia burchellii (Sond. ex Engl.) Moffett & 1.00 & 1 & 1 & 0 \\
\hline Santalaceae & Thesium lineatum L.f. & 1.00 & 1 & 1 & 0 \\
\hline Asteraceae & Euryops annae E.Phillips & 0.86 & 7 & 6 & -1 \\
\hline Rosaceae & Rubus ludwigii Eckl. \& Zeyh. & 0.50 & 2 & 1 & -1 \\
\hline Asteraceae & Felicia filifolia (Vent.) Burtt Davy & 0.50 & 2 & 1 & -1 \\
\hline Asteraceae & Elytropappus rhinocerotis (L.f.) Less. & 0.43 & 7 & 3 & -4 \\
\hline Rosaceae & Cliffortia arborea Marloth & 0.00 & 2 & 0 & -2 \\
\hline Euphorbiaceae & Clutia marginata E.Mey. ex Sond. & 0.00 & 2 & 0 & -2 \\
\hline Melianthaceae & Melianthus comosus Vahl & 0.00 & 3 & 0 & -3 \\
\hline Solanaceae & Lycium cinereum Thunb. & 0.00 & 5 & 0 & -5 \\
\hline
\end{tabular}

